\title{
Generation of monoclonal antibodies specific to hepatopancreatic parvovirus (HPV) from Penaeus monodon
}

\author{
Sombat Rukpratanporn ${ }^{1}$, Wasana Sukhumsirichart ${ }^{2}$, Parin Chaivisuthangkura ${ }^{3}$, \\ Siwaporn Longyant ${ }^{3}$, Weerawan Sithigorngul ${ }^{3}$, Piamsak Menasveta ${ }^{1}$, \\ Paisarn Sithigorngul ${ }^{3, *}$
}

\author{
${ }^{1}$ Marine Biotechnology Research Unit at Chulalongkorn University, National Center for Genetic Engineering \\ and Biotechnology (BIOTEC), Bangkok 10330, Thailand \\ ${ }^{2}$ Department of Biochemistry, and ${ }^{3}$ Department of Biology, Srinakharinwirot University, Bangkok 10110, Thailand
}

\begin{abstract}
Hepatopancreatic parvovirus (HPV) was isolated from the hepatopancreas (HP) of slow growth Penaeus monodon by urografin gradient centrifugation. The presence of HPV in the fraction was monitored by PCR and sodium dodecyl sulphate polyacrylamide gel electrophoresis (SDSPAGE). Only 1 major $54 \mathrm{kDa}$ protein band was observed in the strong PCR-positive fractions used to immunize mice for monoclonal antibody production. After cell fusion, the first step in selecting specific antibodies was performed by dot-blot assay with purified HPV viral particles. The second screening step was carried out using Western blots of purified HPV proteins and immunohistochemistry of HPV-infected HP tissue. Four monoclonal antibodies were isolated; these bound to the $54 \mathrm{kDa}$ protein in Western blots and to intranuclear inclusion bodies in tubule epithelial cells of HPV-infected prawn tissue by immunohistochemistry. None of the antibodies showed cross-reactivity either to uninfected shrimp tissue or to other shrimp viruses tested. These reagents have potential for use in developing a highly sensitive immunoassay such as sandwich ELISA or a convenient kit for detection of HPV infection.
\end{abstract}

KEY WORDS: Dot-blot $\cdot$ Hepatopancreatic parvovirus $\cdot$ HPV $\cdot$ Immunohistochemistry $\cdot$ Monoclonal antibody $\cdot$ Penaeus monodon

\section{INTRODUCTION}

Hepatopancreatic parvovirus (HPV) has been known to infect several penaeid shrimp in Asian, Australian and African regions since 1985 (Lightner et al. 1993). HPV was first reported from Thailand infecting Penaeus monodon in 1993 (Flegel \& Sriurairatana 1993). Shrimp infected with HPV usually show nonspecific gross signs of disease. However, infection is statistically related to retarded growth in $P$. monodon (Flegel et al. 1999). HPV virions are icosahedral, approximately $22 \mathrm{~nm}$ in diameter and contain ssDNA of $6 \mathrm{~kb}$ in size. This probably comprises overlapping genes for at least 2 polypeptides. The virus was classified in the family Parvoviridae based on these characteristics (Bonami et al. 1995, Spann et al. 1997, Sukhumsirichart et al. 1999). Detection was traditionally dependent upon the histological demonstration of basophilic intranuclear inclusions in tubular epithelial cells of the hepatopancreas (HP) by hematoxylin and eosin (H\&E) or Giemsa staining (Lightner 1996). DNA probes and PCR primers have been developed and 
proven to be powerful tools for diagnosis of shrimp HPV infection (Sukhumsirichart et al. 1999, 2002, Pantoja \& Lightner 2000, Phromjai et al. 2001, 2002). Under optimized conditions, DNA approximately equivalent to that in 300 viral particles could be detected (Pantoja \& Lighner 2000). However, there are practical limitations to using PCR in widespread applications. These include the need for special equipment and highly trained personnel and the costs incurred for small sample numbers. Moreover, HPV isolates from various shrimp species and geographic regions seem to be genetically different. For example, HPV in $P$. chinensis from Korea (Bonami et al. 1995), P. monodon from Thailand (Sukhumsirichart et al. 1999) and Macrobrachium rosenbergii from Malaysia (Lightner et al. 1994) are different. PCR primers designed for HPV from $P$. chinensis were not particularly efficient for PCR amplification of HPV DNA from P. monodon (Phromjai et al. 2001) and probes designed from the same source did not hybridize with DNA of HPV from M. rosenbergii (Lightner et al. 1994).

Immunologically based diagnosis, especially using monoclonal antibodies (MAbs), has proven to be an effective, alternative method for diagnosis of various viral diseases including those of shrimp, e.g. yellow head virus (YHV) (Sithigorngul et al. 2002). A series of MAbs specific to YHV was produced, most of which could recognize various isolates of YHV complex such as gill associated virus from Australia and nonvirulent YHV-like virus from Thailand. Few recognized only the virulent YHV isolate from Thailand (Soowannayan et al. 2003). MAbs can be adapted to various formats for use in convenient diagnostic kits. Here we describe preliminary trials to produce a MAb that could be used to develop a specific, sensitive and convenient test kit for HPV detection.

\section{MATERIALS AND METHODS}

Antigen preparation. Growth retarded shrimp Penaeus monodon (1 to $5 \mathrm{~g}$ ) were collected from ponds in Chonburi province, Thailand. Hepatopancreata were dissected out and frozen immediately in liquid nitrogen and stored at $-70^{\circ} \mathrm{C}$ until use. The HP was homogenated in NaCl-Tris-EDTA buffer (NTE; $0.2 \mathrm{M}$ $\mathrm{NaCl}, 0.02 \mathrm{M}$ Tris-HCl, $0.02 \mathrm{M}$ EDTA pH 7.4). Cell debris was removed by centrifugation at both 7000 and $13000 \times g$ for $15 \mathrm{~min}$. The supernatant was centrifuged at $140000 \times g$ for $1 \mathrm{~h}$ and the pellet was resuspended and further separated by gradient ultracentrifugation in $(20$ to $40 \%)$ urografin for $3 \mathrm{~h}$. Fractions were collected, diluted with NTE and centrifuged at $140000 \times g$ for $3 \mathrm{~h}$. Pellets were resuspended in Tris-EDTA buffer (TE; 10 mM Tris-HCl, 1 mM EDTA pH 7.4) at $4^{\circ} \mathrm{C}$ and checked for the presence of HPV by PCR and sodium dodecyl sulphate polyacrylamide gel electrophoresis (SDS-PAGE). Positive fractions were divided into small aliquots and stored at $-70^{\circ} \mathrm{C}$. The viral suspension was used for immunization and for screening of MAbs by dot blot and Western blot analysis.

Part of the purified virus preparation was denatured by mixing with treatment buffer (SDS and $\beta$-mercaptoethanol) dialyzed against phosphate buffered saline (PBS; $0.15 \mathrm{M}, \mathrm{pH} 7.2$ ), then divided into small aliquots and used for immunization. Part of an HPV-infected HP was fixed in Davidson's fixative and processed for paraffin sectioning (Lightner 1996) and used for immunohistochemical screening of antibodies against HPV.

PCR detection of HPV. HPV-specific primers $121 \mathrm{~F}$ (5'GCA CTT ATC ACT GTC TCT AC 3") and 276R (5'GTG AAC TTT GTA AAT ACC TTG 3") were used in PCR amplification (Sukhumsirichart et al. 1999) to yield a $156 \mathrm{bp}$ amplicon specific for HPV. A stored viral fraction was thawed and treated with $50 \mu \mathrm{g} \mathrm{ml}^{-1}$ of Proteinase $\mathrm{K}$ for $30 \mathrm{~min}$ at $37^{\circ} \mathrm{C}$ followed by $0.5 \%$ sarkosyl treatment for $1 \mathrm{~h}$ at $65^{\circ} \mathrm{C}$. The nucleic acid was then extracted using phenol and chloroform-isoamyl alcohol $(24: 1: 1 \mathrm{v} / \mathrm{v})$ and precipitated with $70 \%$ ethanol. The DNA pellet was washed with $70 \%$ ethanol, air dried and resuspended in TE buffer. The purified DNA was amplified by PCR in a $50 \mu$ l reaction mixture (Sukhumsirichart et al. 1999).

Immunization. Three Swiss albino ICR mice were first immunized intraperitoneally with $100 \mu \mathrm{l}$ of denatured HPV (0.2 $\left.\mathrm{mg} \mathrm{ml}^{-1}\right)$ mixed with complete Freund's adjuvant (1:1). The mice were boosted 3 times at 2 wk intervals with the same preparation mixed with incomplete Freund's adjuvant. After the fourth injection, sera were collected and tested for HPV immunoreactivity by immunohistochemistry and Western blot analysis.

Monoclonal antibody production. The best performing mouse was boosted $3 \mathrm{~d}$ before hybridoma production. A cell fusion procedure was adapted from the method developed by Köhler \& Milstein (1976), with modifications described by Mosmann et al. (1979). A P3X myeloma cell line was used as the fusion partner. Fusion products from 1 mouse were plated on 30 microculture plates (96 wells per plate). After identification of positive cultures by the screening methods described below, cells were recloned by the limiting dilution method.

Immuno dot-blots. Purified virus $\left(0.1 \mathrm{mg} \mathrm{ml}^{-1}\right)$ was spotted onto nitrocellulose membranes (1 $\mu \mathrm{l} \mathrm{spot}^{-1}$ ) that were subsequently baked at $60^{\circ} \mathrm{C}$ for $10 \mathrm{~min}$ and then incubated with hybridoma conditioned media from each culture well (1:20 dilution in 5\% Blotto: $5 \%$ nonfat dry milk, $0.1 \%$ Triton-X-100 in PBS) for $4 \mathrm{~h}$. After extensive washing in $0.5 \%$ Blotto, the membrane 
was incubated in horseradish peroxidase conjugated goat anti-mouse immunoglobulin G (IgG) heavy and light chain specific antibody (GAM-HRP; BioRad) at 1:1000 dilution for $3 \mathrm{~h}$. The membrane was then washed as extensively as before and incubated in a substrate mixture containing $0.006 \%$ hydrogen peroxide, $0.03 \%$ diaminobenzidine (DAB), $0.05 \%$ cobalt chloride in PBS. Hybridoma clones producing antibodies that displayed immunoreactivity were confirmed for viral specificity by Western blot and immunohistochemistry before cloning and cryo-preservation for further investigation.

Western blots. Proteins from partially purified HPV were separated by $10 \%$ SDS-PAGE according to the method described by Laemmli (1970). Samples were electrophoresed for $1 \mathrm{~h}$ at $100 \mathrm{~V}$ and part of the gel was stained using Coomassie brilliant blue R-250. For Western blot analysis, the samples resolved by SDSPAGE were electroblotted onto nitrocellulose membranes using a Transblot apparatus (BioRad). The nitrocellulose membrane was incubated in $5 \%$ Blotto for $10 \mathrm{~min}$, treated with 1:200 of each MAb for $4 \mathrm{~h}$ and then processed as described in the dot-blotting section above.

Immunohistochemistry. Cephalothoraces from HPV-infected prawns were fixed in Davidson's fixative solution for $24 \mathrm{~h}$ before processing for paraffin sectioning. Serial sections ( $8 \mu \mathrm{m}$ thickness) were prepared and processed for indirect immunoperoxidase staining using various MAbs and GAM-HRP diluted 1:1000 with $10 \%$ calf serum in PBS. Peroxidase activity was revealed by incubation with $0.03 \% \mathrm{DAB}$ and $0.006 \%$ hydrogen peroxide in PBS. Preparations were counterstained with $\mathrm{H} \& \mathrm{E}$, dehydrated in graded ethanol series, cleared in xylene and mounted in permount (Sithigorngul et al. 1999). Positive reactions were visualized as brown coloration against pink cytoplasm and purple nuclei. Tissues from Penaeus monodon infected with YHV, nonvirulent YHV, monodon baculo virus (MBV) and white spot syndrome virus (WSSV) were also used to determine cross-reactivity of the MAbs by immunohistochemistry.

Monoclonal antibody class and subclass. Class and subclass of mouse IgG produced by the hybridomas were determined by sandwich ELISA using Zymed's Mouse MonoAb ID Kit (HRP).

\section{RESULTS AND DISCUSSION}

SDS-PAGE of proteins from partially purified HPV revealed a major protein band of $54 \mathrm{kDa}$ (Fig. 1A) similar to that reported for HPV from Penaeus chinensis (Bonami et al. 1995). Therefore, the preparation was considered of sufficiently high purity to use for immunization. After the fourth immunization, antisera from all 3 mice bound specifically to basophilic intra-nuclear inclusion bodies of HPV-infected HP tubule epithelial cells in immunohistochemistry assays and strongly to 2 specific protein bands of 54 and $97 \mathrm{kDa}$ in Western blot assays. One mouse was used as a spleen donor and the yield of hybridoma clones was approximately 1000 (30\% of wells from 30 plates). Only 10 clones showed specific binding to viral protein by dot-blot assay. After Western blot and immunohistochemistry analyses, only 4 clones showed specific binding to the $54 \mathrm{kDa}$ protein (Fig. 1B) and to HPV intra-nuclear inclusion bodies but not to uninfected tissues (Fig. 2). Antibodies from these clones also recognized the $97 \mathrm{kDa}$ protein. It may be a precursor of the $54 \mathrm{kDa}$ protein, since it appeared as a minor protein but cross-reacted with the MAb for the major $54 \mathrm{kDa}$ protein. Specificity of the selected MAbs was verified when negative immunohistochemical reactions were obtained in shrimp tissues infected with virulent YHV, nonvirulent YHV, WSSV, and MBV (Table 1). Immunohistochemical studies using MAb HPV16-9C, revealed that some inclusion bodies were not well recognized (Fig. 2). A similar result was observed in in situ hybridization tests using P. monodon HPV probe (Sukhumsirichart et al.

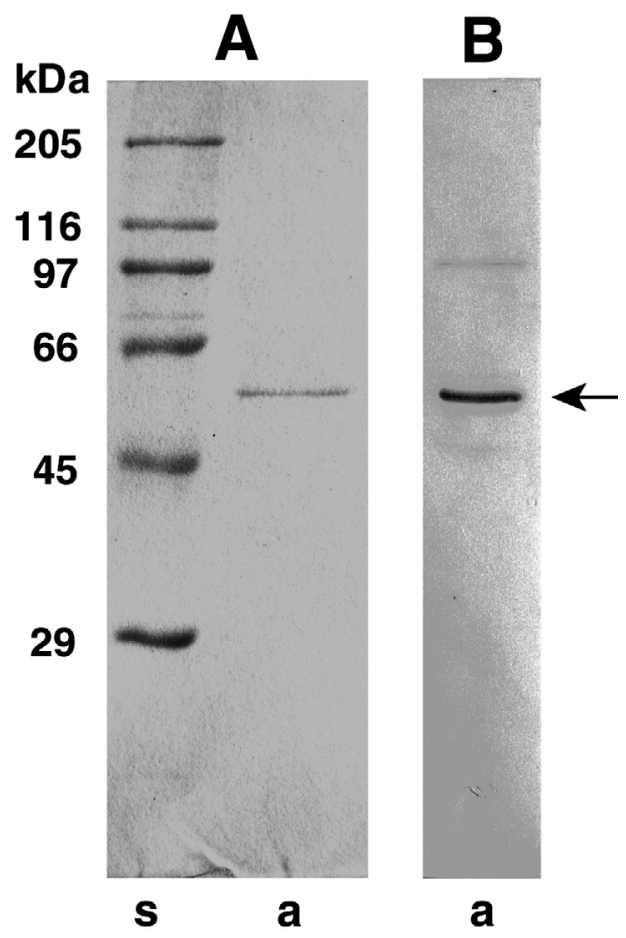

Fig. 1. SDS-PAGE and Western blot analysis. (A) SDS-PAGE of hepatopancreatic parvovirus (HPV) preparation stained with Coomassie blue. (B) Western blot of HPV preparation treated with MAb HPV16-9C that binds to the main HPV protein band at $54 \mathrm{kDa}$ (arrow) and a minor band at $97 \mathrm{kDa}$. s: standard proteins; a: HPV preparation 

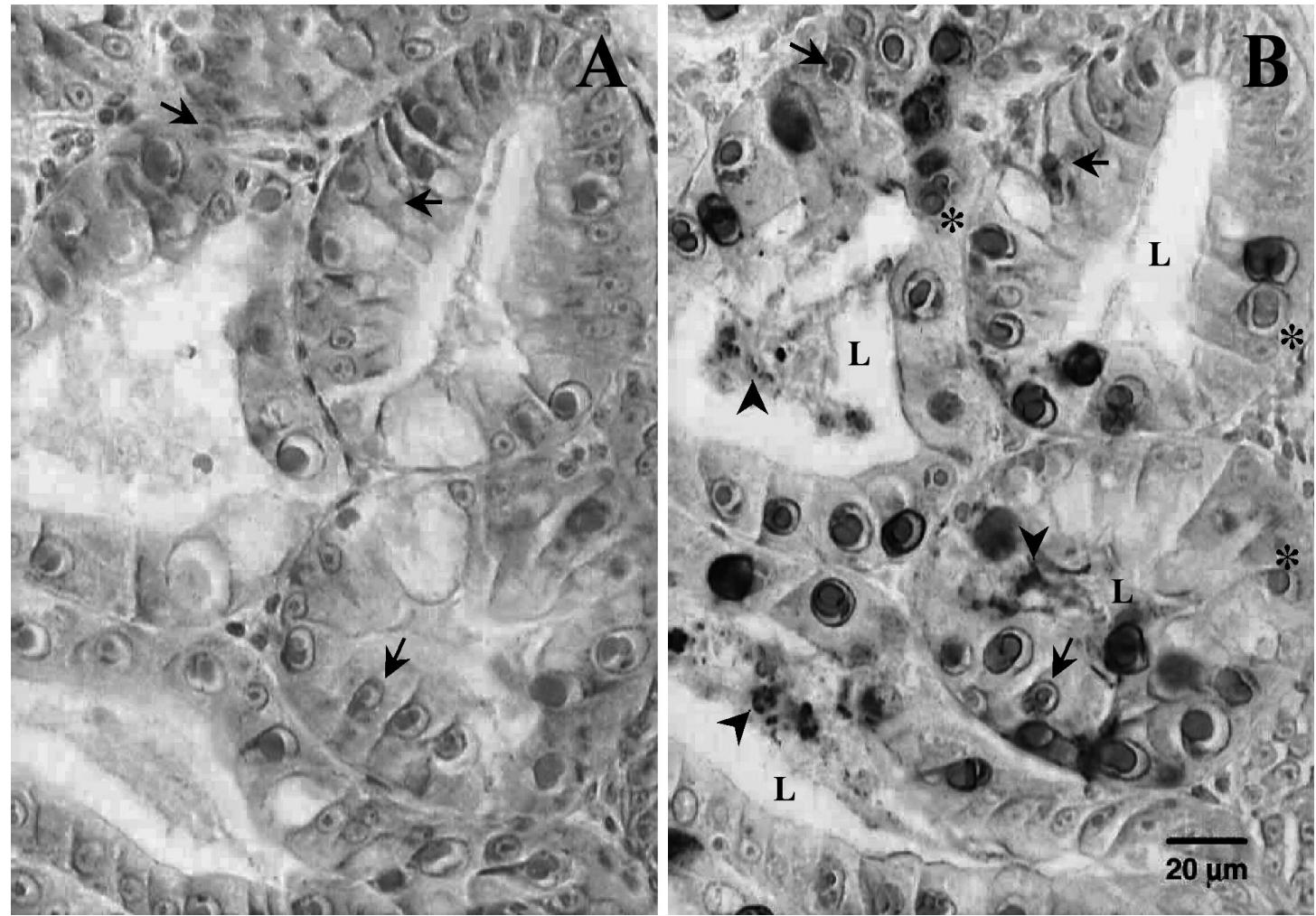

Fig. 2. Penaeus monodon infected by immunohistochemistry of hepatopancreas from HPV-infected P. monodon. (A) Tissue section stained with H\&E without antibody treatment. (B) Adjacent section treated with MAb HPV16-9C and counter stained with H\&E. Arrows indicate immunoreactivity in nuclei at the early stage of HPV infection. HPV immunoreactivity is also observed in the lumen (L) of the HP tubule (arrowhead). With some inclusion bodies, the immunoreactivity is demonstrated only at the peripheral surface $(*)$

1999). The lack of reaction with some inclusion bodies may result from high density preventing $\mathrm{MAb}$ access, or from mixed infections with different types of HPV-like viruses.

Table 1. Characterization of monoclonal antibodies specific to hepatopancreatic parvovirus (HPV). -: no immunoreactivity; +: light immunoreactivity; ++: strong immunoreactivity; MAb: monoclonal antibody; IHC: immunohistochemistry; WSSV: white spot syndrome virus; MBV: monodon baculo virus

\begin{tabular}{|c|c|c|c|c|c|c|c|}
\hline $\begin{array}{l}\text { MAb } \\
\text { (subclass) }\end{array}$ & $\begin{array}{l}\text { Dot } \\
\text { blot }\end{array}$ & $\begin{array}{c}\text { Western } \\
\text { blot }\end{array}$ & IHC & YHV & $\begin{array}{c}\text { YHV } \\
\text { (non- } \\
\text { virulent) }\end{array}$ & WSSV & MBV \\
\hline $\begin{array}{l}\text { HPV6-12B } \\
\left(\operatorname{IgG}_{2 b}\right)\end{array}$ & + & ++ & ++ & - & - & - & - \\
\hline $\begin{array}{l}\mathrm{HPV} 12-10 \mathrm{C} \\
\left(\mathrm{IgG}_{1}\right)\end{array}$ & + & + & + & - & - & - & - \\
\hline $\begin{array}{l}\text { HPV16-9Ca } \\
\left(\operatorname{IgG}_{2 b}\right)\end{array}$ & + & ++ & ++ & - & - & - & - \\
\hline $\begin{array}{l}\text { HPV } 17-1 \mathrm{G} \\
\left(\operatorname{IgG}_{1}\right)\end{array}$ & + & + & + & - & - & - & - \\
\hline
\end{tabular}

All MAbs were of the IgG class. Two were $\operatorname{IgG}_{1}$ and 2 were $\operatorname{IgG}_{2 b}$ (Table 1). The latter 2 appeared to bind to the HPV protein stronger than the former. These MAbs may be useful for further development of a highly sensitive immunoassay such as a sandwich ELISA for HPV detection in feces, similar to the PCR method (Pantoja \& Lightner 2000). A convenient strip test would be another choice for rapid assays in the field. Generation of more MAbs against various epitopes would increase the sensitivity of the assay. Molecular cloning and expression of a high quantity of HPV protein might also be a useful approach for the production of polyclonal antibodies in rabbits.

Acknowledgements. This work was supported by the Research Support Division, Srinakharinwirot University. 


\section{LITERATURE CITED}

Bonami JR, Mari J, Poulos BT, Lightner DV (1995) Characterization of hepatopancreatic parvo-like virus, a second unusual parvovirus pathogenic for penaeid shrimps. J Gen Virol 76:813-817

Flegel TW, Sriurairatana S (1993) Black tiger prawn diseases in Thailand. In: Akiyama DM (ed) Tech Bull American Soybean Assoc, Singapore AQ39/1993 (3), Sect B p 1-30

Flegel TW, Thamavit V, Pasharawipas T, Alday-Sanz V (1999) Statistical correlation between severity of hepatopancreatic parvovirus (HPV) infection and stunting of farmed black tiger shrimp (Penaeus monodon). Aquaculture 174: 197-206

Köhler G, Milstein C (1976) Derivative of specific antibody producing tissue culture and tumor cell fusion. Eur J Immunol 6:511-519

Laemmli UK (1970) Cleavage of structure proteins during the assembly of the head of bacteriophage T4. Nature 227: 680-685

Lightner DV (1996) A handbook of pathology and diagnostic procedures for diseases of penaeid shrimp. World Aquaculture Society, Baton Rouge, LA

Lightner DV, Redman RM, Moore DW, Park MA (1993) Development and application of a simple and rapid diagnostic method to studies on hepatopancreatic parvovirus of penaeid shrimp. Aquaculture 116:15-23

Lightner DV, Redman RM, Poulos BT, Mari JL, Bonami JR, Shariff M (1994) Distinction of HPV-type virus in Penaeus chinesis and Macrobrachium rosenbergii using a DNA probe. Asian Fish Sci 7:267-272

Mosmann TR, Bauman R, Williamson AR (1979) Mutations affecting immunoglobulin light chain secretion by myeloma cells I. Functional analysis by cell fusion. Eur J Immunol 9:511-516

Pantoja CR, Lightner DV (2000) A non-destructive method based on the polymerase chain reaction for detection of hepatopancreatic parvovirus (HPV) of penaeid shrimp. Dis

Editorial responsibility: Timothy Flegel, Bangkok, Thailand
Aquat Org 39:177-182

Phromjai J, Sukhumsirichart W, Pantoja C, Lightner DV, Flegel TW (2001) Different reactions obtained using the same DNA detection reagents for Thai and Korean hepatopancreatic parvovirus of penaeid shrimp. Dis Aquat Org 46:153-158

Phromjai J, Boonsaeng V, Withyachumnarnkul B, Flegel TW (2002) Detection of hepatopancreatic parvovirus in Thai shrimp Penaeus monodon by in situ hybridization, dot blot hybridization and PCR amplification. Dis Aquat Org 51: 227-232

Sithigorngul P, Panchan N, Vilaivan T, Sithigorngul W, Petsom A (1999) Immunochemical analysis and immunohistochemical localization of crustacean hyperglycemic hormone from the eyestalk of Macrobrachium rosenbergii. Comp Biochem Physiol B 124:73-80

Sithigorngul $\mathrm{P}$, Rukpratanporn S, Longyant S, Chaivisuthangkura P, Sithigorngul W, Menasveta P (2002) Monoclonal antibodies specific to yellow-head virus (YHV) of Penaeus monodon. Dis Aquat Org 49:71-76

Soowannayan C, Flegel TW, Sithigorngul P, Slator J and 7 others (2003) Detection and differentiation of yellow head complex viruses using monoclonal antibodies. Dis Aquat Org 57:193-200

Spann KM, Adlard RD, Hudson DA, Pyecroft SB, Jones TC, Voigt MOC (1997) Hepatopancreatic parvo-like virus (HPV) of Penaeus japonicus cultured in Australia. Dis Aquat Org 31:239-241

Sukhumsirichart W, Wongteerasupaya C, Boonsaeng V, Panyim S, Sriurairatana S, Withyachumnarnkul B, Flegel TW (1999) Characterization and PCR detection of hepatopancreatic parvovirus (HPV) from Penaeus monodon in Thailand. Dis Aquat Org 38:1-10

Sukhumsirichart W, Kiatpathomchai W, Wongteerasupaya C, Withyachumnarnkul B, Flegel TW, Boonsaeng V, Panyim S (2002) Detection of hepatopancreatic parvovirus (HPV) infection in Penaeus monodon using PCR-ELISA. Mol Cell Probes 16:409-413

Submitted: May 12, 2004; Accepted: November 17, 2004 Proofs received from author: May 17, 2005 
